http://dx.doi.org/10.21611/qirt.2017.057

\title{
Introduction of Regulatory Guideline of Buried and undergroud piping and tank
}

\author{
Kyungcho Kim ${ }^{1 \dagger}$, Tae-Heum Nam ${ }^{1}$, Jong-Min Kim ${ }^{1}$, Jin-Gyun Kim ${ }^{1}$, Ho-Sang Shin ${ }^{1}$ \\ ${ }^{1}$ Korea Institute of Nuclear Safety, 19 Kusung, Daejeon, KoeraJapan \\ †*Presenting and Corresponding Author: kck@kins.re.kr
}

\begin{abstract}
Leakage from buried and underground pipes caused by corrosion has resulted in recent ground water contamination incidents. Some of these leaks resulted in groundwater contamination incidents with associated heightened USNRC and public interest. So, the industry issued a guidance document, Nuclear Energy Institute (NEI) 09-14, "Guideline for the Management of Buried Piping Integrity" to describe a licensee's goals and required actions resulting from this underground piping and tank initiative. The NRC conducted inspections using TI 2515/173, "Review of the Implementation of the Industry Groundwater Protection Voluntary Initiative" to assess licensee response to these incidents and determine the extent of the industry's voluntary groundwater protection initiative. According to NEI 0914, utility provided procedures, risk ranking, inspection plan and asset management plan These procedures, risk ranking, inspection plan and asset management plan were evaluated by USNRC according to TI 2515/173. The same evaluation and inspection be required according to aging degradation of Korea NPP..

The purpose of this research is to develop regulatory techniques for aging management for buried and underground pipes and tank in Korean Nuclear Power Plant and to develop regulatory guideline for aging management for buried and underground pipes and tank in Korean Nuclear Plants. For this purpose, aging, direct and indirect inspection technique and regulatory technique for buried and underground pipes and tank will be evaluated and database for damage of buried and underground pipe and tank will be developed. From these techniques and database information, in-service inspection guideline and review guideline for aging management will be developed.
\end{abstract}

KEYWORDS: Buried Piping, Aging management, direct and indirect inspection.

\section{Introduction}

Leakage from buried and underground pipes caused by corrosion has resulted in recent ground water contamination incidents. Some of these leaks resulted in groundwater contamination incidents with associated heightened NRC and public interest. The NRC conducted inspections using TI 2515/173, "Review of the Implementation of the Industry Groundwater Protection Voluntary Initiative" to assess licensee response to these incidents and determine the extent of the industry's voluntary groundwater protection initiative. Subsequently, the industry communicated its plan to address buried piping integrity in its November 2009 letter "Industry Initiative on Buried Piping Integrity" The scope of the first underground piping initiative only addressed piping that is directly buried in soil. However, because operating experience which revealed that leakage of tritiated water from underground piping in vaults or chases (but not in contact with soil) could also lead to groundwater contamination, the industry expanded the scope of its first initiative to include underground piping not in direct contact with the soil and selected underground tanks. Its September 2010 letter "Industry Initiative on Underground Piping and Tanks Integrity" describes its revised commitments. This second initiative contains all of the requirements and objectives from the first initiative but adds underground piping and tanks that are outside of a building and below the surface of the ground (whether or not they are in direct contact with the soil) if they are safety-related or contain licensed material or are known to be contaminated with licensed material. Also, an owner's piping located outside the owner controlled area is considered to be within the scope of the underground piping and tanks integrity initiative if it is safety-related or contains licensed material.

The industry issued a guidance document, Nuclear Energy Institute (NEI) 09-14, "Guideline for the Management of Buried Piping Integrity" to describe a licensee's goals and required actions (commitments made by the licensee) resulting from this underground piping and tank initiative. NEI later issued NEI 09-14, Revision 1, "Guidance for the Management of Underground Piping and Tank Integrity," on December 31, 2010. An Electric Power Research Institute (EPRI) document "Recommendations for an Effective Program to Control the Degradation of Buried and Underground Piping and Tanks" is a guidance document that provides additional details on the buried pipe and tank initiative elements and attributes to incorporate into a licensee's buried pipes and tanks program. Alternative documents such as those produced by NACE International also provide acceptable guidance. Under the underground piping and tanks Integrity Initiative, each site is to develop and implement 
either site-specific or company program for buried piping and underground piping and tanks.

According to NEI 0914, utility provided procedures, risk ranking, inspection plan and asset management plan These procedures, risk ranking, inspection plan and asset management plan were evaluated by USNRC according to TI 2515/173. The same evaluation and inspection be required according to aging degradation of Korea NPP..

The purpose of this research is to develop regulatory techniques for aging management for buried and underground pipes and tank in Korean Nuclear Power Plant and to develop regulatory guideline for aging management for buried and underground pipes and tank in Korean Nuclear Plants. For this purpose, aging, direct and indirect inspection technique and regulatory technique for buried and underground pipes and tank will be evaluated and database for damage of buried and underground pipe and tank will be developed. From these techniques and database information, in-service inspection guideline and review guideline for aging management will be developed.

\section{Guideline for the Management of Underground Piping and Tank Integrity(NEI 09-14)}

This Guideline(NEI 09-14) for the Management of Underground Piping and Tank Integrity describes the policy and practices that the industry commits to follow in managing underground piping and tanks. The Underground Piping and Tanks Integrity Initiative superseded the Buried Piping Integrity.

\subsection{Scope and Goal}

The scope of the Underground Piping and Tanks Integrity Initiative includes the following : All buried and underground piping and tanks that are outside of a building and below grade (whether or not they are in direct contact with the soil) if they

- Are safety related or

- Contain licensed material or are known to be contaminated with licensed material or

- Contain environmentally hazardous material.

The Underground Piping and Tanks Integrity Initiative will:

. Drive proactive assessment and management of the condition of piping and tanks that fall within the Initiative scope.

. Ensure sharing of industry experience.

. Drive technology development to improve available techniques for inspecting and analyzing underground piping and tanks.

. Improve regulatory and public confidence in the industry's management of the material condition of its underground tanks and piping systems.

\subsection{Initiative Actions}

A. Original Buried Piping Integrity Initiative Elements

1. Procedures and Oversight. By June, 30, 2010, develop a Buried Pipe Integrity Program document and implementing procedures.

2. Risk Ranking . Risk Rank buried piping segments by December 31, 2010.

3. Inspection Plan. By June 30, 2011, develop an inspection plan to provide reasonable assurance of integrity of buried piping.

4. Plan Implementation. Implementation of the Inspection Plan shall start no later than June 30, 2012. The condition assessment of buried piping containing radioactive material shall be completed by December 31, 2014.

5. Asset Management Plan . Inspection results shall be used as input to the development of an asset management plan for buried piping. This plan shall receive a high level of review and approval and will be in place by December 31, 2014.

B. Underground Piping and Tanks Integrity Initiative Elements

1. Procedures and Oversight. By December 31, 2011

2. Prioritization . Prioritize underground piping and tanks by June 30, 2012.

3. Condition Assessment Plan(s) . By December 31, 2012 develop or identify existing condition assessment plans that will provide reasonable assurance of integrity of components within the additional scope of the Underground Piping and Tanks Integrity Initiative.

4. Plan Implementation . Implementation of the Condition Assessment Plan for underground piping and tanks shall start no later than June 30, 2013

5. Asset Management Plan . Inspection results shall be used as input to the development of asset management plans for components within the scope of the Underground Piping and Tanks Integrity Initiative. These plans shall receive a high level of review and approval and will be in place by December 31, 2014.

\subsection{Industry Roles and Responsibilities}




\section{A. Utilities}

Implement the actions required by the Initiative, Report all results from inspections of piping and tanks within the scope of the Initiative, Report to INPO's Consolidated Event System ( ICES) all occurrences of leakage and adverse inspection findings as required for the report to NSIAC.

B. EPRI

Collect underground piping and tank inspection data obtained from utilities and evaluate its implications annually, Manage the research necessary to improve inspection technology for underground piping and tanks, Support repair/replacement technology as appropriate, Provide a venue for identifying research and development needs, sharing operating experience, and other issues that have the potential for impact on the industry

C. INPO

Incorporate within their plant evaluations a review of buried/underground piping and tank programs as applicable. The review should include piping and tanks that may not be safety related but are important to safety, contain licensed material, or contain environmentally hazardous fluids. Communicate operating experience relative to underground piping and tank integrity issues and other relevant information to the industry. Compile and report to NEI the operating experience information necessary to make periodic reports to NSIAC

D. NEI

Manage the industry's regulatory interface on underground piping and tank issues of generic regulatory significance, Manage the operation of the Buried Piping Integrity Task Force.

\section{NRC Inspection Manual for Underground Piping and Tank(TI 2525-182)}

The objective of this TI is to determine whether licensees are implementing the industry initiative on underground piping and tank integrity and to gather information that will enable the staff of the U.S. Nuclear Regulatory Commission (NRC) to assess whether the initiative provides reasonable assurance of the structural and leakage integrity of buried piping and underground piping and tanks. The information collected using this TI will be used to determine the extent of the industry's implementation of the voluntary initiative and to aid in evaluating whether additional NRC regulatory actions are warranted.

\subsection{General Guidance}

In Staff Requirements Memorandum (SRM) SECY 11-0019 the Commission approved the staff's approach to "monitor the effectiveness of the industry initiatives" (NEI 09-14). In completing this TI the NRC inspection staff shall assess whether the licensee has successfully completed the commitments described in NEI 09-14 Rev. 3, as revised, Sections 3.3 a and b. This assessment will be conducted in two phases. In the first phase the NRC inspection staff will determine if the organization of the licensee's program and due dates contained in the program match the organization and due dates contained in NEI 09-14 Rev. 3. Also in this phase the NRC inspection staff will determine whether the licensee has met applicable due dates. In the second phase NRC inspection staff will review the implementation of the licensee's program in sufficient detail to provide responses to a specific set of questions.

\subsection{Phase 1 Required Inspection}

A. The inspector should review the licensee's programs for buried pipe and underground piping and tanks to ensure that the attributes recommended in NEI 09-14 Rev. are contained in the licensee's program. These attributes are listed in sections $3.3 \mathrm{~A}$ and 3.3 B of NEI 09-14 Rev. 3

B. The inspector should review the licensee's programs for buried pipe and underground piping and tanks to ensure that the completion dates recommended in NEI 09-14 Rev. 3 are contained in the licensee's program. These completion dates are listed in sections 3.3 A and 3.3 B of NEI 09-14 Rev. 3, and have been amended by the industry letter in February, 2013. The revised completion dates are listed in Table 1.

C. The inspector should review the licensee's programs for buried pipe and underground piping and tanks to ensure that activities which correspond to completion dates specified in the program which have passed have been completed.

D. The inspector may review any additional aspects of the program that may reveal either good or poor practices in managing buried piping or underground piping and tanks.

E. Phase 1 of the TI should be completed by June 30, 2013.

\subsection{Phase II Required Inspection}


A. The inspector should review the licensee's programs for buried pipe and underground piping and tanks to ensure that activities which correspond to completion dates specified in the program which have passed since the Phase 1 inspection was conducted, have been completed.

B. The inspector should review the licensee's programs in sufficient breadth and depth so as to be able to prepare written responses to the questions contained in

http://portal.nrc.gov/edo/nrr/dirs/irib/Inspection\%20Manual\%20Forms\%20Templates\%20Attachments/Forms/AllItems.aspx.

C. The inspector may review any additional aspects of the program that, in his or her opinion, may reveal either good or poor practices in managing buried piping or underground piping and tanks.

D. Phase 2 of the TI should be completed by June 30, 2014.

\section{CONCLUSIONS}

In this research, guideline for the management of underground piping and tank integrity(NEI 09-14) and NRC Inspection Manual for underground piping and tank was reviewed. According to USA experience, utility will provide information for buried and underground piping and tank and regulatory body inspected buried and underground piping and tank. By reviewing these experience of USA, KINS, Korean regulatory body will develop regulatory techniques for aging management for buried and underground pipes and tank in Korean Nuclear Power Plant and to develop regulatory guideline for aging management for buried and underground pipes and tank in Korean Nuclear Plants. From these techniques in-service inspection guideline and review guideline for aging management will be developed.

\section{References}

[1] Guidance for the management of uncerground piping and tank ingegrity(NEI 09-14)

[2] NRC INSPECTION MANUAL TEMPORARY INSTRUCTION 2515/182

[3] License Renewal Interim Staff Guidance LR-ISG-2011-03, Changes to the generic aging lessons learned (GALL) report revision 2 aging management program XI.M41, "BURIED AND UNDERGROUND PIPING AND TANKS" 